\title{
ANALISIS REAKSI PASAR TERHADAP PENGUMUMAN RIGHT ISSUE (STUDI KASUS PADA SAHAM YANG TERDAFTAR DI ISSI)1
}

\author{
Moch. Ali Fudin Al Islami \\ Departemen Ekonomi Syariah-Fakultas Ekonomi dan Bisnis-Universitas Airlangga \\ Email: moch.ali.fudin-2014@feb.unair.ac.id \\ Imron Mawardi \\ Departemen Ekonomi Syariah-Fakultas Ekonomi dan Bisnis-Universitas Airlangga \\ Email: ronmawardi@yahoo.co.id
}

\begin{abstract}
:
This research aims to find out and explain market reactioncaused by existing action corporate advertisement which is the right issue done by the issuer who was listed in Indonesia Sharia Stock Index period 2014-2016.There are 20 issuers who become the research sample with the period of observation is 29 days. The approach used in this research is quantitative approach by using event study method which is the approach that is specialized to analyze a particular event that is believed to have an impact or reaction. The focus of the research is to see the reaction shown by the change of Average Abnormal Return and Trading Volume Activity using one sample t-test and paired sample t-test. Data processing used a statistical tool of Stata version 14 by determining level of significance of $5 \%$. The results of the research show that there is a significant average abnormal return before and after the right issue and there is a significant difference in trading volume activity before and after the right issue.
\end{abstract}

Keywords: Sharia Stock, Right Issue, Abnormal Return, Trading Volume Activity.

\section{PENDAHULUAN}

Semakin pesatnya pertumbuhan ekonomi suatu negara, maka peran pasar modal menjadi sangat penting sebagai sarana menghimpun dana dari pelaku bisnis dan juga masyarakat. Dalam proses penghimpunan dana oleh perusahaan dan penyaluran dana oleh investor dapat dilakukan melalui mekanisme jual-beli saham di pasar modal perdana. Menurut Husnan (2005:3) pasar modaldidefinisikan sebagai pasar untuk berbagai instrumen keuangan (sekuritas) jangka panjang yang bisa diperjual belikan baik dalam bentuk hutang maupun modal, baik yang diterbitkan oleh pemerintah, maupun perusahaan swasta.
Berkembangnya ekonomi islam di indonesia menjadi salah satu pelopor utama dalam meningkatkan kesadaran masyarakat muslim untuk dapat bertransaksi di pasar modal yang sesuai dengan norma-norma islam atau prinsip syariah, hal tersebut dibuktikan dengan dibentuknya produk-produk syariah seperti saham syariah, reksadana syariah serta sukuk, selain itu juga terdapat indeks saham syariah dipasar modal seperti Jakarta Islamic Indeks (JII) dan Indeks Saham Syariah Indonesia (ISSI).

Pasar modal tidak akan lepas dari fenomena aksi korporasi perusahaanemiten dimana perusahaan akan melakukan corporate action dalam

\footnotetext{
${ }^{1}$ Jurnal ini merupakan bagian dari skripsi yang ditulis oleh Moch Ali Fudin Al Islami, NIM: 041411431026, yang diuji pada 15 Januari 2018.
} 
rangka memenuhi tujuan-tujuan tertentu, misalnya pembayaran kewajiban jatuh tempo, perluasan usaha, meningkatkan likuiditas dan tujuan perusahaan lainnya. Umumnya corporate action mempunyai pengaruh yang signifikan terhadap kepentingan pemegang saham, karena pada corporate action yang dilakukan umumnya akan berpengaruh pada jumlah saham yang beredar, komposisi kepemilikan saham, jumlah saham yang akan dipegang pemilik saham serta pengaruhnya terhadap pergerakan harga saham .Salah satu bentuk aksi korporasi perusahaan yaitu right issue.Berkaitan dengan hal tersebut penawaran terbatas atau disebut right issue merupakan salah satu cara yang ditempuh untuk memperoleh sumber dana. Terdapat dua alasan bagi perusahaan untuk melakukan right issue: pertama, dapat mengurangi biaya karena right issue biasanya tidak menggunakan jasa penjamin (underwriter). kedua, right issue menyebabkan jumlah saham perusahaan yang ada akan bertambah sehingga diharapkan akan meningkatkan frekuensi perdagangan atau yang berarti meningkatkan likuiditas saham (Hermuningsih dan Wardani, 2009).

Pengumuman right issue oleh perusahaan dianggap mengandung information content yang dapat mempengaruhi nilai perusahaan yang tercermin dalam harga saham, dan sebagai investor yang rasional dan tanggap akan merespon setiap perubahan informasi tertentu untuk menentukan keputusan investasi nya (Hermuningsih dan Wardani, 2009). Jogiyanto (2009:537) menerangkan ada hal yang dapat dicermati berkaitan dengan adanya reaksi terhadap corporate action, yaitu: "Reaksi ini dapat diukur dengan menggunakan return sebagai nilai perubahan harga atau dengan menggunakan abnormal return". Selain itu hal lain yang dapat dicermati berkaitan dengan adanya reaksi pasar yaitu tingkat volume perdagangan, hal tersebut sesuai dengan pendapat Susanto (2002) dalam Rusdi dan Avianto (2009) yang menyatakan bahwa likuiditas saham meningkat secara signifikan setelah pengumuman right issue. Peningkatan volume perdagangan saham tersebut ditemukan mempunyai korelasi dengan perubahan struktur kepemilikan saham, dimana right issue lebih diutamakan untuk tujuan konsentrasi kepemilikan daripada perluasan kepemilikan.

\section{Rumusan Masalah}

Dari uraian latar belakang yang telah dijelaskan diatas, maka permasalahan yang akan diteliti dalam penelitian dapat dirumuskan sebagai berikut:

1. Apakah terdapat Abnormal Return terhadap right issuepada emiten yang terdaftar di Indeks Saham Syariah Indonesia?

2. Apakah terdapat perbedaan Average Abnormal Returnsebelum dan sesudah 
pengumuman right issue pada emiten yang terdaftar di Indeks Saham Syariah Indonesia?

3. Apakah terdapat perbedaan Trading Volume Activity (TVA) sebelum dan sesudah pengumuman right issuepada emiten yang terdaftar di Indeks Saham Syariah Indonesia?

\section{Tujuan Penelitian}

Tujuan penelitian ini adalah untuk menguji apakah terdapat reaksi pasar yang tercermin dari adanya abnormal return di sekitar tanggal pengumuman, , serta melihat perbedaan average abnormal return dan trading volume activity sebelum dan sesudah pengumuman.

\section{LANDASAN TEORI}

\section{Pasar Modal}

Pasar modal menurut Jogiyanto (2003:11) merupakan sarana perusahaan untuk meningkatkan kebutuhan dana jangka panjang dengan menjual saham atau mengeluarkan obligasi. Sedangkan menurut Husnan (1994:3) secara formal pasar modal didefinisikan sebagai pasar untuk berbagai instrumen keuangan (atau sekuritas) jangka panjang yang bias diperjual-belikan, baik dalam bentuk hutang ataupun modal sendiri, baik yang diterbitkan oleh pemerintah,maupun perusahaan swasta.

\section{Corporate Action}

Corporate Action menurut (Maguire: 2007) yaitu "An event initiated by a company that affects its share". Yang artinya adalah Corporate Action merupakan suatu event atau kegiatan yang digagas oleh perusahaan yang mempengaruhi pangsa pasarnya sendiri, sedangkan menurut Kustodian Sentral Efek Indonesia (KSEI) memberikan definisi tentang corporate action yaitu,"setiap tindakan perusahaan terdaftar yang memberikan hak kepada seluruh pemilik manfaat atas efek dari jenis dan kelas yang sama seperti hak untuk memperoleh dividen tunai, dividen saham, bunga, saham bonus, penawaran umum terbatas, warran atau hak-hak lainnya."

\section{Right Issue}

Istilah right issue dapat didefinisikan sebagai kegiatan penawaran umum terbatas kepada pemegang saham lama dalam rangka penerbitan hak memesan efek terlebih dahulu. Instrumen investasi ini merupakan turunan atau derivatif dari saham. Menurut Hermuningsih dan Wardani (2009) right issue merupakan pengeluaran saham baru dalam rangka penambahan modal perusahaan, namun terlebih dahulu ditawarkan kepada pemegang saham saat ini lexisting share holder) dengan kata lain pemegang saham memiliki preemptiveright atau hak memesan efek terlebih dahulu, atas saham-saham baru tersebut.

\section{Efisiensi Pasar}

Terdapat tiga bentuk tingkatan efisiensi pasar menurut Fama dalam Samsul (2006:

270):

a. The weak efficient market hypothesis

Efisiensi pasar dikatakan lemah (weakform) karena dalam proses 
pengambilan keputusan jual beli saham investor menggunakan data harga dan volume masa lalu. Berdasarkan harga dan volume perdagangan masa lalu berbagai model analisis teknis digunakan untuk menentukan arah harga apakah akan naik atau akan turun. Analisis teknis mengasumsikan bahwa harga saham selalu berulang kembali.

b. The semistrong efficient market hypothesis

Efisiensi pasar dikatakan setengah kuat (semistrong-form) karena dalam proses pengambilan keputusan jual beli saham, investor menggunakan data harga masa lalu, volume masa lalu, dan semua informasi yang dipublikasikan.

c. The strong efficient market hypothesis Efisiensi pasar dikatakan kuat (strongform) karena investor menggunakan data yang lebih lengkap yaitu harga masa lalu, volume masa lalu, informasi yang di publikasikan, dan informasi privat yang tidak dippublikasikan secara umum. Perhitungan harga estimasi yang lebih lengkap dapat menghasilkan keputusan jual beli saham yang lebih tepat dan return yang lebih tinggi.

\section{Event Study}

$$
\text { Jogiyanto (2009: 537) }
$$

menyatakan bahwa pengujian kandungan informasi dan pengujian efisiensi pasar bentuk setengah kuat merupakan dua pengujian yang berbeda. Pengujian kandungan suatu informasi dimaksudkan untuk melihat reaksi suatu pengumuman. Jika pengumuman mengandung informasi (information content), maka diharapkan pasar akan bereaksi pada waktu pengumuman tersebut diterima oleh pasar. Reaksi pasar atas sebuah pengumuman corporate action menurut (Jogiyanto 2009: 537) ini diukur dengan menggunakan return sebagai nilai perubahan harga atau dengan menggunakan abnormalreturn.Kandungan informasi yang ada kemudian diuji untuk melihat reaksi suatu pengumuman. Harapan pasar akan bereaksi oleh pengumuman yang diterima, jika pengumuman mengandung informasi.

\section{Signaling Theory}

Menurut Brigham dan Houston (2001:36) isyarat atau signal adalah suatu tindakan yang diambil perusahaan untuk memberi petunjuk bagi investor tentang bagaimana manajemen memandang prospek perusahaan. Sinyal ini berupa informasi mengenai apa yang sudah dilakukan oleh manajemen untuk merealisasikan keinginan pemilik

\section{Return}

Return saham adalah tingkat keuntungan yang dinikmati oleh pemodal atas suatu investasi yang dilakukannya. Pasar saham tidak menjanjikan suatu return yang pasti bagi para investor. Namun berharap komponen return pada saham yang memungkinkan investor 
meraih keuntungan adalah deviden, saham bonus, dan capital gain (Robert dalam Utomo, 2015). Jogiyanto (2009:199) mengatakan bahwa return merupakan hasil yang diperoleh dari investasi. Return dapat berupa return realisasian yang sudah terjadi atau return ekspektasi yang belum terjadi tetapi yang diharapkan akan terjadi di masamendatang.

Return realisasi (realized return) merupakan return yang telah terjadi yang dihitung berdasarkan data return historis. Return historis ini juga berguna sebagai dasar penentu return ekspektasi (expected return) dan resiko di masa yang akan datang. Return realisasi penting karena digunakan sebagai salah satu indikator kinerja suatu perusahaan.

Rit $=\frac{P t-P t-1}{P t-1}$

Keterangan

Rit $=$ Return saham i pada periode $\dagger$

$\mathrm{Pt}=$ Harga saham pada periode $\dagger$

Pt-1 = Harga saha pada periode $\mathrm{t}-1$ Return pasar atau pendapatan pasar yaitu return acuan dalam menentukan return ekspektasi pada model market adjustmendengan rumus sebagai berikut :

$R m t=\frac{\text { IHSG }- \text { IHSG }-1}{\text { IHSG }-1}$

Keterangan:

$\mathrm{Rm} t=$ Pendapatan pasar sahamke- $\dagger$

IHSG†= Indeks Harga Saham Gabungan

padahari ke- $\dagger$

IHSG+-1 = Indeks Harga Saham Gabungan pada hari ket
Hubungan Antara Right Issue terhadap Abnormal Return dan Trading Volume Activity

Reaksi pasar pada pasar bentuk setengah kuat dapat dilihat dari abnormal return. Seperti dijelaskan oleh Jogiyanto (2009:537), Reaksi ini ini dapat diukur dengan menggunakan return sebagai nilai perubahan harga atau dengan menggunakan abnormal return. average abnormal return merupakan rata-rata abnormal return (AR) dari semua jenis saham yang dianalisis secara harian (Samsul, 2006:276)

Menurut Husnan (1996: 111-112), Volume Aktivitas Perdagangan saham dapat digunakan untuk melihat apakah investor secara individu menilai suatu peristiwa sebagai suatu yang informatif, dalam arti, apakah informasi tersebut akan membuat keputusan investasi yang berbeda dari keputusan investasi normal. Suatu informasi mengandung nilai informatif jika jumlah lembar saham yang diperdagangkan menjadi lebih besar atau lebih kecil pada saat peristiwa terjadi, dibandingkan dengan waktu lainnya.

\section{Average Abnormal Return}

Pasar bereaksi jika ada pengumuman corporate action.Menurut Jogiyanto (2009:537), reaksi ini dapat diukur dengan menggunakan return sebagai nilai perubahan harga atau dengan menggunakan abnormal return". 
Perhitungan abnormal return menggunakan rumus berikut:

ARit $=$ Rit - Rmt

Keterangan :

ARit= Abnormal Return sekuritas-i pada periode peristiwa ke- $\dagger$

Rit=Actual Return sekuritas ke-i pada periode peristiwa ke- $\dagger$

Rmt= Pendapatan pasar sekuritas ke-i untuk periode peristiwa ke- $\dagger$

Average Abnormal Return (AAR) dirumuskan dengan :

$\mathrm{AARt}=\frac{1}{N} \sum_{i=1}^{n}$ ARit

Keterangan:

AARt $=$ Pendapatan abnormal rata-rata pada periode $\dagger$

$\mathrm{n}=$ Jumlahsaham

ARit= Pendapatan abnormal saham i padaperiode- $\dagger$

\section{Trading Volume Activity (TVA)}

Trading Volume Activity (TVA) atau

Volume Aktivitas Perdagangan Saham adalah perbandingan saham yang diperdagangkan pada waktu tertentu dengan jumlah saham yang beredar di pasar.Volume Aktivitas Perdagangan adalah suatu metode untuk menguji reaksi pasar terhadap suatu informasi.Pengujian reaksi pasar modal dengan menggunakanpendekatanVolume

Aktivitas Perdagangan telah dilakukan oleh Beaver (1968). Kegiatan perdagangan saham diukur dengan menggunakan indikator sebagai berikut:

TVAit $=\frac{\Sigma \text { saham yang diperdagangkan pada waktu } t}{\Sigma \text { saham yang beredar di BEI pada waktu } t}$

\section{Hipotesis}

terdapat tiga hipotesis pada penilitan ini, antara lain sebagai berikut : Hla: Terdapat abnormal return atas pengumuman right issue

Hib: Terdapat perbedaan abnormal return sebelum dan sesudah pengumuman right issue

HIc: Terdapat perbedaan trading volume activity sebelum dan sesudah pengumuman right issue.

\section{METODE PENELITIAN}

\section{Jenis dan Pendekatan Penelitian}

Penelitian ini menggunakan jenis penelitian kuantitatif dan dengan metode event study. Penelitian event study merupakan studi yang mempelajari reaksi pasar terhadap suatu peristiwa (event) yang informasinya dipublikasikan sebagai suatu pengumuman (Jogiyanto, 2009 seperti dikutip dalam skripsi Jasmine, 2015). Peristiwa yang diamati adalah peristiwa pengumuman right issuedengan melihatreaksiyangterjadidipasaryaitudeng an tolak ukur adanya abnormal returndan trading volume activity.

Periode penelitian ini yaitu selama 29 hari dengan tujuan untuk mengamati harga saham 14 hari (t-14) sebelum terjadinya right issue, $t=0$ saat terjadinya right issue, dan 14 hari $(t+14)$ setelah terjadinya right issue. Alasan peniliti dalam menentukan waktu pengamatan selama 29 hari ialah untuk mengantisipasi terjadinya reaksi dini sebelum pengumuman right issue yang dilakukan oleh perusahaan emiten. Penelitian ini 
menggunakan indikatorsample paired ttest yang diolah menggunakan aplikasi STATA 14.

\section{Metode Pengambilan Sampel}

Penelitian ini bertujuan untuk meneliti pengaruh dari pengumuman right issueterhadap volume perdagangan dan return saham sehingga sampel dari penelitian ini masuk ke dalam jenis purposive sampling. Sugiyono (2012:85) mengatakan bahwa purposive sampling adalah teknik penentuan sampel dengan pertimbangan tertentu. Berikut merupakan kriteria sampel yang digunakan sebagai data:

1. Emiten yang terdaftar pada indeks saham syariah indonesia periode 2014-2016 pada saat melakukan aksi korporasi right issue

2. Perusahaan yang masuk dalam kriteria penelitian tidak melakukan aksi korporasi selain right issue

3. Saham perusahaan yang aktif diperdagangkan minimal 14 sebelum dan sesudah tanggal pengumuman right issue untuk mengetahui seberapa besar pengaruh right issue terhadap Average Abnormal Return dan Trading Volume Activity.

\section{Tekhnik Analisis}

Untuk membuktikan hipotesis yang diajukan bahwa right issueakan mempengaruhi average abnormal return (AAR) dan trading volume avtivity (TVA) saham, maka akan dilakukan analisisberdasarkanteori- teoriyangmendukungpenelitian. Langkahlahngah dalam melakukan tekhnik analisis sebagai berikut :

1. Mengidentifikasi event yang akan dijadikan acuan penelitian. Yaitu pengumuman right issue oleh emiten saham syariah yang terdaftar di Indeks Saham Syariah Indonesia pada periode2014-2016

2. Periode pengamatan yang digunakan dalam penelitian ini selama 29 hari, yaitu 14 hari sebelum tanggal right issue (t-14), (t-0) saat terjadinya right issue, dan 14 hari setelah tanggal right issue $(t+14)$.

3. Menghitung pendapatan masingmasing saham

4. Menghitung pendapatan pasar saham

5. Menghitung Abnormal Return (AR) periode sebelum dan sesudah tanggal right issue

6. Menghitung rata-rata Average Abnormal Return (AAR) periode sebelum dan sesudah tanggal right issue

7. Menghitung Trading Volume Activity (TVA) periode sebelum dan sesudah tanggal right issue

8. Melakukan uji normalitas dengan menggunakan aplikasi STATA ver. 14 untuk mengetahui bahwa distribusi sampel telah normal dan siap diuji secara statistik dengan uji normalitas Shapiro-Wilk W test.

9. Melakukan uji hipotesis 1 dengan aplikasi STATA ver. 14menggunakan uji one sample t-test, untuk menguji reaksi 
pasar atas right issue.Sampel yang diolah adalah hasil dari Average Abnormal Return (AAR) sebelum dan sesudahperistiwaright issuedenganmenentukanlevelofsignific ant(LOS) sebesar5\%.

10. Melakukan uji hipotesis 2 dan 3 dengan aplikasi STATA ver. 14. Dari hasil uji kenormalan data, maka tahapan uji hipotesis yang diambil adalah sebagai berikut :

1) Jika data berdistribusi normal, maka tekhnik uji beda dua sampel berpasangan yang digunakan adalah Paired Sample t-Test yang merupakan uji statistik parametrik. Langkah-langkah dalam pengujian ini yaitu :

a. Menentukan level of significance (a), yaitu sebesar $5 \%$ dengan derajat kebebasan (df) sebesar n-1

b. Membandingkan probabilitas (p) t-hitung dengan $a=5 \%$. Penarikan kesimpulan pada uji ini yaitu didasarkan pada :

- Apabila nilai probabilitas (p) < 0,05 maka HO ditolak.

- Apabila niilai probabilitas (p) > 0,05 maka HO diterima

2) Jika data tidak berdistribusi normal, maka tekhnik uji beda dua sampel berpasangan yang digunakan adalah Uji Peringkat Wilcoxon (Wilcoxon Signed Rank Test) yang merupakan uji statistik non parametrik (Latan 2014: 317)
Langkah-langkah dalam pengujian ini adalah :

a. Menentukan level of significance (a), yaitu sebesar $5 \%$ dengan derajat kebebasan (df) sebesar n-1

b. Membandingkan probabilitas (p) z-hitung dengan $a=5 \%$. Penarikan kesimpulan pada uji ini yaitu didasarkan pada :

- Apabila nilai probabilitas (p) $<0,05$ maka HO ditolak.

- Apabila nillai probabilitas (p) > 0,05 maka HO diterima

\section{ANALISIS DAN PEMBAHASAN}

\section{Uji Normalitas}

Jenis uji normalitas yang digunakan adalah uji Saphiro-Wilk normality test. Jika data terbukti terdistribusi normal maka dapat dilanjutkan pengujian one sample t-test dan paired sample t-test. Jika data tidak terdistribusi secara normal selanjutnya akan dilakukan uji peringkat Wilcoxon (Wilcoxon Signed Rank Test). Apabila dalam perhitungan diperoleh nilai signifikan $\geq 0,05$ maka data tersebut berdistribusi normal. Sebaliknya, jika nilai signifikan $\leq 0,05$ maka data tidak berdistribusi normal.

Tabel 1.

Hasil Uji Normalitas

\begin{tabular}{|c|c|c|c|}
\hline No & Variabel & Prob > z & Keterangan \\
\hline 1 & $\begin{array}{c}\text { AAR } \\
\text { sebelum }\end{array}$ & 0,73053 & Normal \\
\hline 2 & $\begin{array}{c}\text { AAR } \\
\text { sesudah }\end{array}$ & 0,92187 & Normal \\
\hline
\end{tabular}




\begin{tabular}{|c|c|c|c|}
\hline 3 & $\begin{array}{c}\text { TVA } \\
\text { sebelum }\end{array}$ & 0,00437 & Tidak \\
\hline 4 & $\begin{array}{c}\text { TVA } \\
\text { sesudah }\end{array}$ & 0,62524 & Normal \\
\hline
\end{tabular}

Sumber : Data diolah, 2018

Berdasarkan hasil uji normalitas diatas menunjukkan bahwa nilai probabilitas z AAR sebelum dan sesudah lebih besar dari 0,05, sehingga dapat disimpulkan bahwa data AAR terdistribusi normal. TVA sebelum memiliki nilai dibawah 0,05, sedangkan TVA sesudah diatas 0,05 sehingga nila TVA dapat disimpulkan tidak terdistribusi secara normal.

\section{Analsisis Average Abnormal Return dengan Uji One Sample t-Test}

Pengujian menggunakan one sample t-test bertujuan untuk mengetahui apakah terdapat reaksi dari pasar yang ditunjukkan dengan adanya abnormal return pada periode disekitar tanggal pengumuman right issue. Berikut merupakan uji one sample t-Test.

\section{Tabel 2.}

\section{Hasil Uji One Sample t-Test}

\begin{tabular}{|l|l|}
\hline Ha: mean $<0$ & $\operatorname{Pr}(T<t)=0,2060$ \\
\hline Ha: mean $>0$ & $\operatorname{Pr}(T>t)=0,7940$ \\
\hline
\end{tabular}

Sumber diolah, 2018

$$
\text { Hasil dari uji one sample t-test }
$$

pada average abnormal return didapatkan hasil hitung dengan nilai probabilitas $\operatorname{Pr}(T<t)=0,2060$ dan $\operatorname{Pr}(T>t)=$ 0,7940 . Sehingga dapat disimpulkan bahwa nilai probabilitas dari keduanya lebih dari 0,05 yang artinya tidak terdapat reaksi abnormal return secara statistik disekitar event date.

\section{Analisis Average Abnormal Return dengan} Uji Paired Sample t-Test

Tujuan dari pengujian ini adalah untuk membuktikan adanya perbedaan average abnormal return sebelum dan sesudah pengumuman right issue. Berikut merupakan hasil perhitungan uji paired sample t-test pada average abnormal return menggunakan alat bantu Stata ver. 14.

\section{Tabel 3.}

Hasil Paired Sample t-Test

\begin{tabular}{|l|l|}
\hline Ha: mean $<0$ & $\operatorname{Pr}(\mathrm{T}<\dagger)=0.7623$ \\
\hline Ha: mean $>0$ & $\operatorname{Pr}(\mathrm{T}>\dagger)=0.4753$ \\
\hline
\end{tabular}

Sumber diolah, 2018

Hasil dari uji paired sample t-test pada average abnormal return didapatkan hasil hitung dengan nilai probabilitas $\operatorname{Pr}(T<t)=0.7623$ dan $\operatorname{Pr}(T>t)=$ 0.4753. Sehingga dapat disimpulkan bahwa nilai probabilitas dari keduanya lebih dari 0,05 yang artinya tidak terdapat perbedaan average abnormal return secara statistik sebelum dan sesudah right issue.

\section{Analisis Trading Volume Activity dengan Wilcoxon Signed Rank Test}

Tujuan dari uji ini yaitu untuk melihat perbedaan sebelum dan sesudah pengumuman right issue atas perubahan trading volume activity. Uji wilcoxon digunakan karena pada subbab sebelumnya hasil dari uji normalitas pada TVA dinyatakan tidak normal, sehingga uji sample paired t-test tidak dapat 
digunakan. Data berikut merupakan hasil uji Wilcoxon signed rank test pada trading volume activity dengan menggunakan aplikasi stata ver. 14.

Tabel 4.

Hasil Uji Wilcoxon Sign Rank Test

\begin{tabular}{|l|l|}
\hline Hasil Pengujian & Value \\
\hline$Z$ & 4.703 \\
\hline Prob $>|z|$ & 0.0000 \\
\hline
\end{tabular}

Sumber diolah, 2018

Dari hasil uji diatas menunjukkan bahwa probabilitas nilai z sebesar 0,0000 atau kurang dari 0,05 yang artinya bahwa $\mathrm{Ha}$ diterima atau HO ditolak. sehingga dapat disimpulkan bahwa terdapat perbedaan yang signifikan atas rata-rata aktivitas transaksi volume perdagangan saham (TVA) sebelum dan sesudah pengumuman.

\section{Pembahasan}

Informasi mengenai right issue merupakan informasi penting yang dapat mempengaruhi jumlah permintaan dan penawaran saham, hal tersebut merupakan sinyal bagi para manajer kepada shareholder atas kondisi perusahaan pada periode berjalan.Informasi mengenai right issue ditanggapi berbeda oleh investor yang tercermin dari reaksi pasar.Informasi yang bersifat informatif dapat merubah preferensi investor dalam pengambilan keputusan investasinya.

Pengujian reaksi pasar terhadap kandungan informasi dari suatu pengumuman dapat diukur menggunakan abnormal returndan trading volume activity. Hasil pengolahan data dan pengujian hipotesis pada abnormal return menunjukkan bahwa tidak terdapat reaksi yang signifikan secara statistik atas pengumuman right issue dari adanya perubahan return. Hal ini mendukung penelitian yang dilakukan oleh Lianawati dan Darmayanti (2015), Nugraha dan Daud (2013) yang tidak menemukan adanya perbedaan average abnormal return sebelum dan sesudah pengumuman. Berikut merupakan grafik average abnormal return pada pengamatan harian.

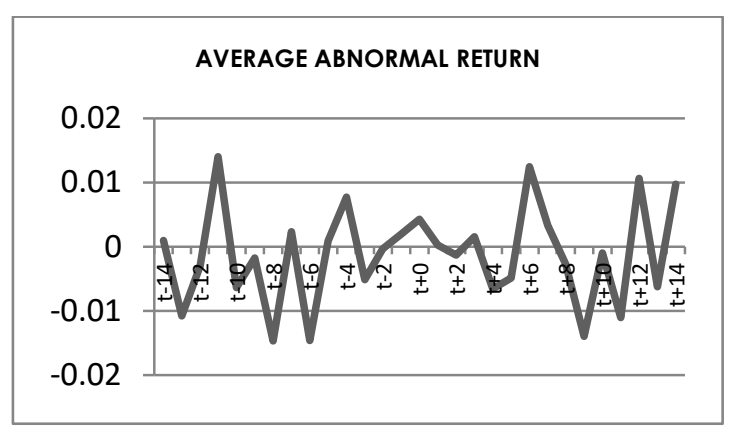

Sumber: Data Sekunder, Diolah

Gambar 1.

\section{Grafik Average Abnormal Return Selama Periode Pengamatan}

Pada grafik diatas menunjukkan bahwa rata-rata abnormal return mengalami penurunan pada t-13, t-8 dan t-6, meskipun pada saat menjelang pengumuman yakni t-4 hingga $t+4$, averageabnormal return cendurung fluktuatif dengan rentang stabil. Terdapatnya nilai rata-rata average abnormal return negatif sebelum pengumuman mengindikasikan bahwa telah terjadi kebocoran informasi yang menyebabkan tidak adanya perubahan 
abnormal return yang signifikan secara statistik menjelang event date. Hal ini sejalan dengan pendapat Husnan (1998: 274) yang menyatakan bahwa dalam kondisi pasar setengah kuat (semi-strong form efficiency) setelah suatu informasi menjadi milik pasar, maka investor tidak bisa memperoleh abnormal return.

Hasil pengolahan data dan pengujian hipotesis pada trading volume activity menunjukkan bahwa terdapat reaksi yang signifikan secara statistik atas pengumuman right issue dari adanya perubahan rata-rata volume saham yang ditransaksikan antara sebelum dan sesudah. Volume perdagangan cenderung mengalami peningkatan setelah pengumuman right issue. Berikut merupakan grafik pada pengamatan harian.

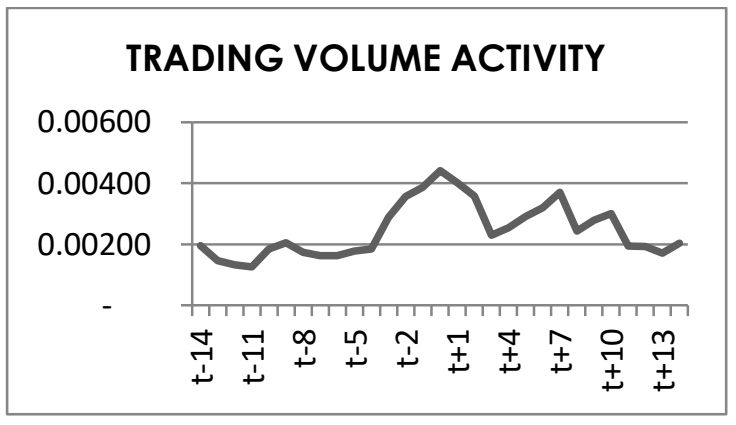

Gambar 2.

\section{Grafik Trading Volume Activity Selama Periode Pengamatan}

Sumber: Data Sekunder, Diolah

Dari grafik data diatas menunjukkan bahwa terdapat perubahan rata-rata volume perdagangan saham antara sebelum dan sesudah pengumuman dengan nilai rata-rata mulai mengalami kenaikan yaitu pada $t-2$ hingga t+2 pengumuman. Nilai rata-rata volume perdagangan saham tertinggi terjadi ketika periode pengumuman, sehingga dapat disimpulkan bahwa terjadi reaksi pasar atas right issue yang ditandai dengan meningkatnya volume perdagangan setelah pengumuman. Secara teoritis tujuan perusahaan dalam melakukan aksi korporasi right issue selain untuk menghimpun dana dari investor, melainkan juga untuk meningkatkan likuiditas saham dengan cara menambah jumlah saham yang beredar, penambahan ini akan menyebabkan tekanan terhadap saham lama. Tekanan ini menyebabkan penurunan terhadap harga saham setelah right issue, yang diharapkan dapat menaikkan likuiditas saham. Selain faktor tersebut semakin meningkatnya jumlah saham yang beredar menyebabkan nilai rata-rata transaksi saham juga semakin besar.

\section{KESIMPULAN DAN SARAN}

\section{Kesimpulan}

Berdasarkan hasil analisis dan pembahasan, maka penelitian Analisis Reaksi Pasar terhadap pengumuman right issue Pada Emiten yang Terdaftar Di ISSI periode 2014-2016,dapat ditarik kesimpulan bahwa terdapat perbedaan trading volume activity atas pengumuman right issuetetapi tidak pada average abnormal return.

\section{Saran}

Berdasarkan pembahasan dan simpulan yang telah dikemukakan, maka 
saran-saran yang dapat diberikan sebagai berikut :

1. Bagi penelitian selanjutnya, diharapkandapatmenyempurnakan kekurangan dalam penelitian ini seperti mengetahui pasti alasan perusahaan melakukanright issue, selain itu pada penelitian selanjutnya dapat dilakukan dengan menggunakan uji korelasi dan regresi.

2. Bagi emiten, pengumuman right issue dapat disampaikan secara resmi beserta alasan serta rencana penggunaan dana yang dihimpun dari hasil right issue agar lebih transparan bagi investor maupun calon investor yang akan berinvestasi.

3. Bagi investor, sebaiknya dalam pengambilan keputusan investasi didasari oleh niat mencari ridho Allah SWT dengan menghindari unsur spekulasi, maysir dan gharar. Oleh sebab itu, setiap adanya aksi korporasi perusahaan khususnya right issue, investor dapat melihat terlebih dahulu kondisi fundamental emiten terkait.

\section{DAFTAR PUSTAKA}

Beaver, William H. 1968. The Information Content of Annual Earning Releases : A Trading Volume Approach. Supplement to journal of Accounting Research

Brigham, Eugene dan Joel F Houston, 2001. Manajemen Kevangan II. Jakarta:Salemba Empat

Hermuningsih, Sri., Wardani D, K. (2009). Analisis Reaksi Pasar Modal
Terhadap Peristiwa Right Issue Dan

Pengumuman Deviden Yang Ditunjukkan Oleh Abnormal Return.Yogyakarta. Fakultas Ekonomi Universitas Sarjanawiyata Tamansiswa. ISSN:2086-0390.

Husnan, Suad. (1994). Dasar-Dasar Teori Portofolio dan Analisis Sekuritas. Edisi I. Yogyakarta: Penerbit UPP AMP YKPN

Husnan, Suad. (1996). Dasar-dasar teori portofolio dan analisis sekuritas. Edisi II. Yogyakarta: UPP AMP YKPN

Husnan, Suad. (2005). Dasar-dasar teori portofolio dan analisis sekuritas. Edisi v. Yogyakarta: UPP AMP YKPN

Indonesian Stock Exchange. 2017. Indonesian Capital Market Directory 2017.

Jasmine, Aldila., (2015). Reaksi Pasar Terhadap Stock Split Pada Emiten Saham Syariah Yang Terdaftar Di Bursa Efek Indonesia Periode 20112014. Surabaya. Fakultas Ekonomi dan Bisnis Universitas Airlangga.

Jogiyanto, H. M. (2003). Teori Portofolio dan Analisis Investasi. Edisi Ketiga. Yogyakarta: BPFE Universitas Gajah Mada.

Jogiyanto, H. M. (2009). Teori Portofolio dan Analisis Investasi. Edisi Keenam. Yogyakarta: BPFE Universitas Gajah Mada.

Latan, Hengky. (2014). Aplikasi Analisis Data Statistik Untuk IImu Sosial Sains Dengan Stata. Bandung. Alfabeta. Maguire, Frances. "The Banker". 2007. 
Rusdi, Dedi dan Avianto, Angga.(2009).

Pengaruh Right Issue Terhadap

Tingkat Keuntungan Dan Likuiditas

Saham Emiten Di Bursa Efek

Jakarta. Fakultas Ekonomi

Universitas Islam Sultan Agung

Samsul, Mohammad. 2006. Pasar Modal

dan Manajemen Portofolio.

Jakarta: Erlangga

Sugiyono. 2012. Metode Kuantitatif,

Kualitatif dan R\&D. Cetakan ke-

17. Bandung: Alfa Beta

Utomo,V.J. 2015. "Efek Hari Libur Lebaran

Pada Emiten yang Terdaftar dalam

ISSI Periode 2011-2013"

Surabaya.Fakultas Ekonomi dan

Bisnis Universitas Airlangga.

(www.ksei.co.id/services/corporate_actio

n_services, diakses tanggal 10

Oktober 2017)

IDX Fact Book 2016.Bursa

Efek Indonesia. Jakarta

IDX Annualy Statistics

2014.Bursa Efek Indonesia. Jakarta

IDX Annualy Statistics

2015.Bursa Efek Indonesia. Jakarta

IDX Annualy Statistics

2016.Bursa Efek Indonesia. Jakarta Undang-Undang No. 8

Tahun 1995 Tentang Pasar Modal 